\title{
PENGEMBANGAN MULTIMEDIA TUTORIAL UNTUK MEMFASILITASI KOGNITIF PROSEDURAL
}

\author{
Luluk Pramita Sari, I Nyoman Sudana Degeng, Henry Praherdhiono \\ Jurusan Teknologi Pendidikan, Fakultas Ilmu Pendidikan, Universitas Negeri Malang \\ Jalan Semarang 5 Malang 65145 0341-574700 \\ Lulukpramita0@gmail.com

\section{Article History} \\ Received: 1 September 2020, Accepted: 12 Desember 2020, Published: 28 Mei 2021
}

\begin{abstract}
Abstrak
Penelitian pengembangan bertujuan menghasilkan produk multimedia tutorial yang layak memfasilitasi kognitif prosedural siswa. Penelitian ini ialah Research and Development. Acuan model yang digunakan yaitu model menurut Lee \& Owens. Review produk multimedia tutorial dilaksanakan oleh ahli materi dan ahli media. Uji coba produk melibatkan 6 audiens kelas V SDN 1 Sumberdadap Tulungagung. Simpulan data hasil review produk memperoleh tanggapan positif dalam kategori layak.
\end{abstract}

Keyword: Multimedia Tutorial; Memfasilitasi Pembelajaran; Kognitif Prosedural

\begin{abstract}
Development research aims to produce multimedia tutorials that are feasible to facilitate student cognitive procedural. This research is Research and Development. The reference model used is the model according to Lee $\&$ Owens. Multimedia tutorial product reviews are carried out by material experts and media experts. The product trial was involved by 6 class V SDN 1 Sumberdadap Tulungagung audiences. It can be concluded that the product review data received positive responses in the proper category.
\end{abstract}

Keyword: Put 3-5 your keywords here in Bahasa Indonesia; keywords separated by semicolon 


\section{PENDAHULUAN}

Proses pembelajaran adalah sistem rangkaian komponen saling terikat serta berinteraksi untuk mencapai rumusan tujuan. Mencapai tujuan secara efektif diperlukan suatu kerangka kerja atau taksonomi. Taksonomi terdiri dari dimensi proses kognitif dan dimensi pengetahuan. Penyusun dimensi pengetahuan yaitu pengetahuan konseptual, pengetahuan faktual, pengetahuan metakognitif, dan pengetahuan prosedural (Anderson \& Krathwohl, 2010). Dimensi pengetahuan penting untuk dikaji, khususnya pada pengetahuan prosedural.

Pengetahuan prosedural ialah ilmu cara bagaimana melakukan sesuatu, seperti ilmu keterampilan, algoritma, metode maupun teknik. Pengetahuan prosedural biasa disebut rangkaian langkah atau prosedur (Anderson \& Krathwohl, 2010). Menurut Khamidah L. (2017) pengetahuan prosedural adalah ilmu pengetahuan berisi langkah-langkah cara ditetapkan untuk mencari jalan keluar permasalahan, serta menjadi acuan cara menjelaskan dan membenarkan penyelesaian masalah.

Kelancaran pengetahuan prosedural ialah kemampuan harus ada dan dikuasai oleh siswa dalam belajar. Tiga aspek kelancaran prosedural, yaitu efisien, fleksibel, dan efektif (Aprianti, 2014). Siswa mengalami banyak kesulitan apabila kelancaran prosedur belum dikuasai. Pada dasarnya siswa mencerna materi prosedur menggunakan hafalan tanpa pemahaman, sedangkan apabila siswa belajar menggunakan pemahaman dapat memodifikasi atau menyesuaikan prosedur untuk mudah digunakan.

Khamidah L. (2017) dalam penelitiannya menemukan permasalahan bahwa banyak siswa belum memahami teknik maupun prosedur dalam menjawab secara dengan benar, tercermin dari siswa ketika masih memiliki sifat ketergantungan bantuan dalam menyelesaikan masalah. Kesalahan tersebut sering ditemui pada kesalahan memilih tanda operasi, kesalahan perhitungan, serta kesalahan membuat kesimpulan (Paridjo, 2019). Kesalahan prosedural dilakukan siswa saat diberikan pertanyaan yang dimodifikasi, meskipun demikian masih ada yang kesulitan menggunakan langkah-langkah untuk penyelesaiannya.

Permasalahan juga terjadi di SDN 1 Sumberdadap Tulungagung oleh siswa kelas V materi subtema bagaimana tubuh mengolah makanan. Diantaranya yaitu pada rendahnya pengetahuan siswa pada materi prosedural tersebut. Terbukti hasil nilai indikator pencapaian yang masih dibawah nilai ratarata. Pada evaluasi diakhir materi siswa kesulitan dengan soal, seperti mengurutkan langkah-langkah dengan benar pada proses bagaimana tubuh mengolah makanan. Selain itu media yang dijadikan alat bantu mengajar pada materi tersebut masih kurang mendukung. Menurut pemaparan guru kelas V SDN 1 Sumberdadap, gambar yang bersumber pada modul atau buku wajib menjadi alat bantu belajar. Guru merasa mempunyai banyak kendala untuk mencontohkan gambaran atau ilustrasi bagaimana proses tubuh dalam mengolah makanan.

Berdasarkan permasalahan tersebut, perlu diadakannya upaya perbaikan. Upaya yang dikira efektif menjadi solusi yaitu pengadaan media pembelajaran. Media ialah segala berhubungan dengan alat perantara guna menyalurkan isi pesan dan informasi dari sumber untuk penerima pesan dalam pembelajaran (Mahnun, 2012). Media sebagai perantara mampu menjembatani siswa terhadap isi materi yang sedang dipelajari. Siswa lebih terdorong belajar jika ditunjang suatu fasilitas media yang modern dan bervariasi. Pemilihan media diharuskan secara tepat sesuai dengan kebutuhan guna tercapai tujuan (Dewanti, dkk., 2019). Pemanfaatan media dengan kreatif mampu meningkatkan serta memperlancar efesiensi tujuan pembelajaran tercapai secara maksimal (Kurniawati \& Nita, 2018).

Media bermacam-macam, salah satunya yaitu multimedia tutorial. Tutorial ialah kondisi belajar siswa dengan melalui prosedur pembelajaran yang telah tersusun penyajian materi. Ciri dan tujuan khusus model tutorial yaitu individual dan pembelajaran dengan tuntas (Yuliana \& Jaenudin, 2015). Multimedia model tutorial mempunyai struktur rangkaian alur diawali dengan tampilan halaman 
orientasi, selanjutnya penyajian isi atau materi, selanjutnya soal disertai respons, diakhir terdapat penilaian hasil latihan soal, serta review materi, dan penutup program (Alessi \& Trollip, 2001). Berbantuan multimedia tutorial siswa mampu mengoperasikan mandiri dengan petunjuk dan latihan pengulangan materi sesuai kebutuhan pemahaman siswa.

Tutorial dapat dioperasikan melalui tatap muka ataupun jarak jauh. Tutorial memenuhi syarat belajar secara mandiri. Tutorial mampu memicu maupun memacu kemandirian, inisiatif pada diri siswa meminimalisasi ketergantungan guru. Tutorial memiliki prinsip yaitu kemandirian siswa berlatih mempelajari materi (Aryani \& Gundo, 2014). Penggunaan tutorial memungkinkan mengatur kecepatan belajar, kapasitas pelajaran serta urutan pelajaran. Namun upaya pemanfaatan media ini masih harus diimbangi oleh keberadaan peran guru.

Berdasarkan keberadaan masalah yang sudah dijelaskan bahwa pengadaan multimedia tutorial menjadi alternatif dalam memfasilitasi kognitif prosedural. Menurut Larasati \& Yunianta., (2017) bahwa dalam mengembangkan kelancaran pengetahuan prosedural siswa perlu dilakukan latihan secara konsisten dan terus menerus. Latihan siswa dengan mandiri memudahkan menanamkan konsep/pengetahuan prosedur dan menunjang keberhasilan belajar (Hartono \& Noto, 2017).

Pengunan multimedia tutorial dapat memberikan pengalaman yang lebih dibandingkan media lainnya. Pemanfaataan multimedia tutorial mampu mengatasi cara belajar siswa secara mandiri mengenai materi bersifat prosedur, dapat berinteraksi langsung, melihat gambar beserta penjelasannya, animasi, video dan latihan soal evaluasi pemahaman materi. Tahapan-tahapan materi disajikan secara runtut. Apabila siswa belum menyelesaikan materi pertama, maka belum dapat meloncat ke materi selanjutnya. Hal tersebut memicu siswa menjadi tertantang mengikuti proses rangkaian materi disajikan. Serta pada akhir materi siswa mendapat review nilai hasil mengerjakan latihan evaluasi.

Sejalan hasil penelitian Anas, dkk., (2019) bahwa pembelajaran tutorial memiliki efek positif dan linear terhadap kemampuan hasil belajar. Dalam penelitian Jannah, I. N. (2020) menunjukkan multimedia meningkatkan pembelajaran IPA kelas V SDN Lamper Tengah 02 Semarang secara efektif. Diungkap Hanim, dkk., (2016) dalam hasil penelitiannya menunjukkan pemanfaatan multimedia efektif dikarenakan memberi pengaruh dan memudahkan agar lebih mengingat saat narasi maupun gambar/animasi ditayangkan bersama. Manfaat multimedia lebih banyak dengan melihat, mendengar bahkan berinteraksi melibatkan indera daripada hanya menggunakan teks ataupun hanya gambar. Multimedia tutorial berpengaruh terhadap peningkatan hasil akhir siswa, hal tesebut media mampu memberikan kemudahan memahami materi yang diberikan, daripada hanya memanfaatkan sumber dari buku saja (Prayoga, dkk., 2016).

Penelitian ini bertujuan menghasilkan produk multimedia tutorial untuk memfasilitasi kognitif prosedural siswa. Serta mengetahui kelayakan produk digunakan dalam proses pembelajaran. Pembeda penelitian ini dengan penelitian yang sudah ada yaitu multimedia tutorial dikembangkan berfokus untuk memfasilitasi kognitif prosedural siswa.

\section{METODE}

Model pengembangan yang dipakai ialah model menurut Lee \& Owens (2004). Alasan pemilihan model tersebut menjadi acuan ialah beberapa tahapan yang disampaikan dengan rinci dan lengkap. Terdapat lima tahapan dalam model tersebut, pertama Assesment/analysis yaitu analisis kebutuhan, analisis awal \& akhir; kedua yaitu desain (Design); ketiga yaitu pengembangan (Development); keempat yaitu implementasi (Implementation); terakhir yaitu evaluasi (Evaluation). Pemilihan model ini dirasa sangat tepat dijadikan acuan dalam mengembangkan produk multimedia tutorial. Model ini ialah model khusus yang ditujukan untuk pengembangan produk multimedia pembelajaran. 


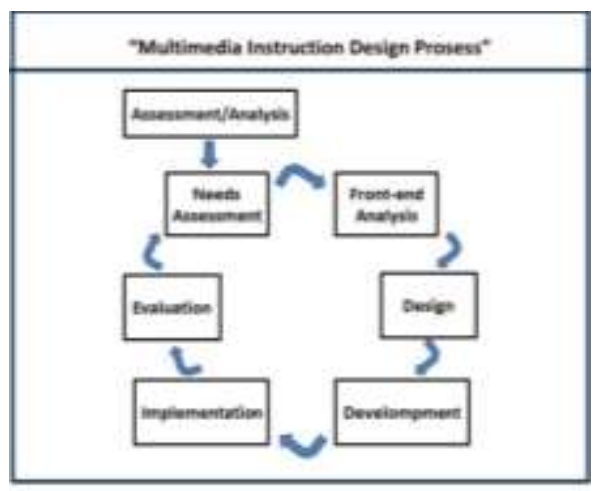

Gambar 2. Model Willliam W. Lee \& Diana L. Owens

Subjek penelitian pengembangan terdiri dari ahli media dan ahli materi serta audiens kelas V SDN 1 Sumberbendo Tulungagung. Review produk dilakukan ahli media dan ahli materi. Setelah dikatakan layak, kemudian produk dilakukan uji respon kepada audiens. Tahap uji coba melibatkan audiens kelas V SDN 1 Sumberbendo Tulungagung sejumlah 6 orang.

Jenis data yang dihasilkan adalah data kuantitatif dan data kualitatif. Data kualitatif berupa deskriptif atau tanggapan, saran dan masukan selama penelitian dilakukan dari para ahli. Sedangkan data kuantitatif adalah data berwujud angka yang diolah menjadi data deskriptif. Dalam pembahasan ini, berasal dari angket diisi oleh subjek penelitian.

Penilaian review ahli materi dan ahli media menggunakan jenis pengukuran skala likert. Kisi-kisi pengumpulan data ahli materi memuat kriteria aspek kelayakan isi, aspek kelayakan penyajian dan aspek kelayakan kebahasaan. Kemudian kisi-kisi instrumen ahli media memuat kriteria sisi kelayakan design media yang dikembangkan.

\section{HASIL}

\section{Need Assesment}

Tahapan pertama yaitu Need Assesment dilakukan dengan observasi maupun wawancara guru dan audiens di SDN 1 Sumberbendo. Tujuannya adalah mengetahui beberapa masalah di sekolah tersebut sehingga arah pengembangan dapat ditentukan. Hasil observasi guru kelas $\mathrm{V}$ bahwa siswa mempunyai kesulitan mengenai materi tematik pada bagian langkah-langkah proses bagaimana tubuh mengolah makanan, sehingga hasil ulangan siswa banyak kesulitan menjawab pada pertanyaan tersebut. Diidentifikasi bahwa kemampuan kognitif prosedural siswa terdapat masalah perlu diupayakan. Dalam pembelajaran, biasanya guru maupun siswa menggunakan modul atau buku, kurangnya ilustrasi mengakibatkan siswa kesulitan memahami materi bersifat prosedural. Sesuai dengan analisis kebutuhan, multimedia tutorial diperlukan sebagai referensi upaya pemanfaatan media yang tepat.

\section{Front-end Analysis}

Pada tahap Front-end Analysis guna mendapatkan berbagai informasi secara detail mengenai produk/media yang dikembangkan. Tahap ini yaitu audience analysis, technology analysis, situation analysis, task analysis, crritical analysis, abjective analysis, issue analysis, media analysis, extant-data analysis dan cost analysi. Bertujuan menjadikan gambaran pelaksanaan langkah berikutnya. Tujuan pembelajaran dapat dirumuskan dan memperkecil hambatan saat mengimplementasikan produk/media.

\section{Design}

Tahap desain atau perencanaan media. Tahap ini ialah keseluruhan pengembangan media. Pengembangan menyusun jadwal (schedule), menentukan spesifikasi media (media spesification), struktur konten (content structure), kemudian kontrol konfigurasi (configuration control). Proses ini meliputi perencanaan flowchart, storyboard, serta antar muka pemakai. 


\section{Development \& Implementation}

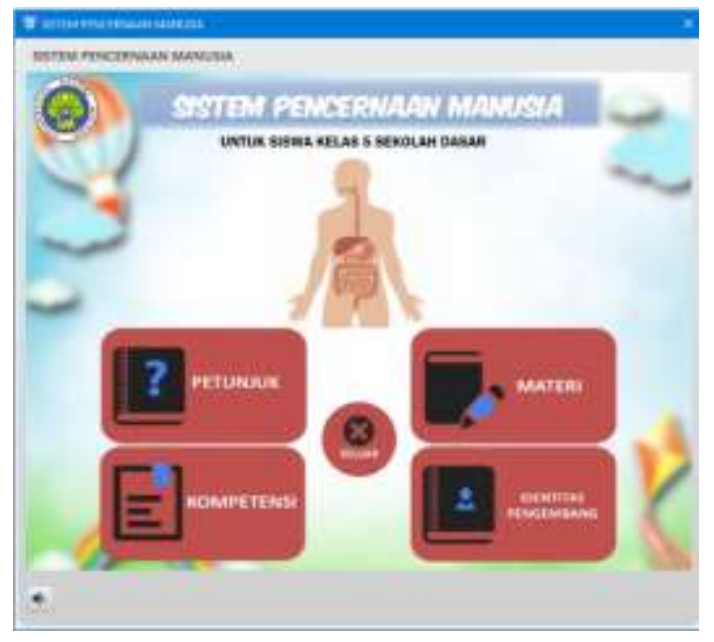

Gambar 3. Tampilan Desain Multimedia Tutorial

Tahap selanjutnya yaitu development \& implementation. Software yang dimanfaatkan dalam mengembangkan produk yaitu Articulate Storyline 3 sebagai penyusun multimedia, Microsoft Power Point untuk memproses gambar serta untuk memproses audio menggunakan Audacity. Setelah produk selesai dibuat, tahap berikutnya yaitu tahap review dan uji coba terhadap subyek penelitian.

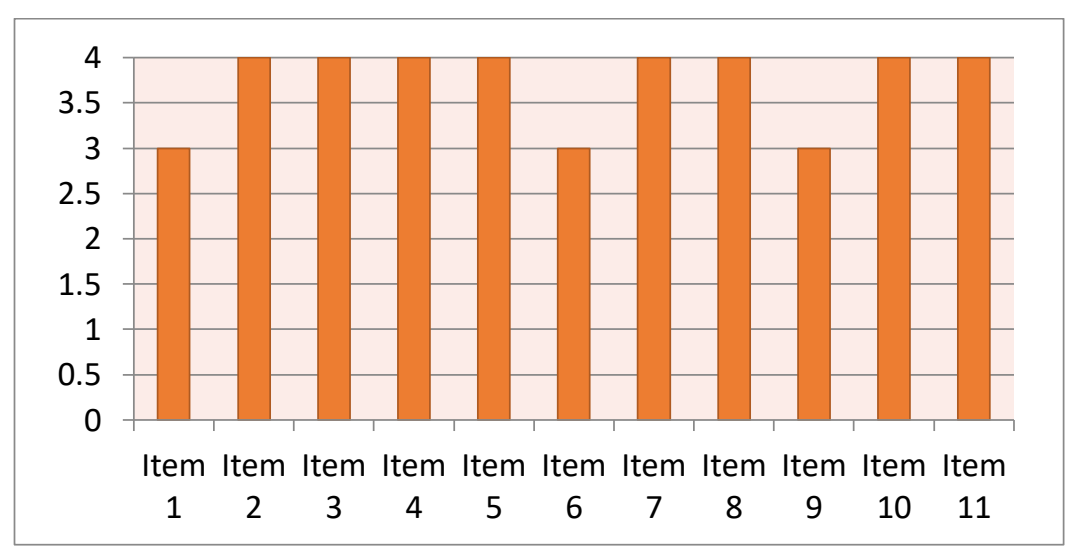

Gambar 4. Hasil Review Ahli Media

Dengan berpedoman hasil konversi rerata skor pada gambar 4. penilaian hasil review oleh ahli media untuk menguji kelayakan produk. Disimpulkan bahwa hasil review terhadap keseluruhan instrumen diperoleh rata-rata skor sebesar 3,72 dari 4,00 dan termasuk kategori layak. Instrumen terdapat 3 aspek indikator dengan 11 item pernyataan. 8 item pernyataan memperoleh skor 4 dan 3 item pernyataan dengan skor 3. Ahli media juga memberikan saran dan komentar pada media yang dikembangkan.

Dengan berpedoman hasil konversi rerata skor pada gambar 5. penilaian hasil review oleh ahli materi untuk mengetahui kelayakan materi produk. Disimpulkan bahwa hasil review terhadap keseluruhan instrumen diperoleh rerata skor sebesar 3,85 dari 4,00 dan dikategorikan layak. Instrumen terdapat 10 aspek indikator dengan 22 item pernyataan. 17 item pernyataan mendapatkan skor 4 , dan 5 item pernyataan dengan skor 3. Ahli materi memberikan komentar multimedia tutorial secara menyeluruh sudah bagus dan materi telah sesuai. 


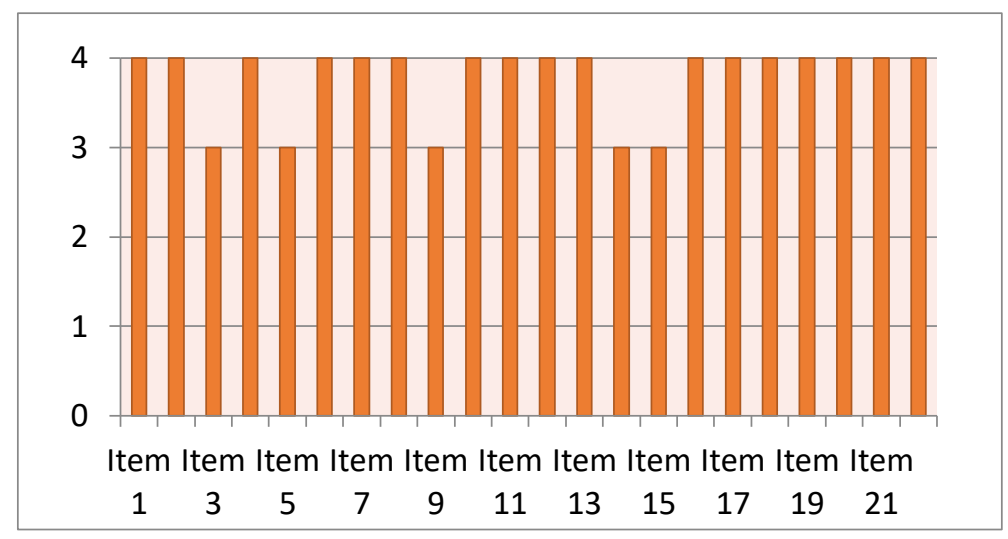

Gambar 5. Hasil Review Ahli Materi

Uji coba produk melibatkan 6 siswa kelas V SDN 1 Sumberdadap Tulungagung. Dengan berpedoman hasil konversi rerata skor pada gambar 6 . hasil dari 15 item pernyataan angket respon siswa mendapatkan rerata skor sebesar 3,85 dari 4,00 dan termasuk kategori sangat baik. Beberapa siswa menyampaikan respon positif terhadap penggunaan multimedia tutorial dalam pembelajaran.

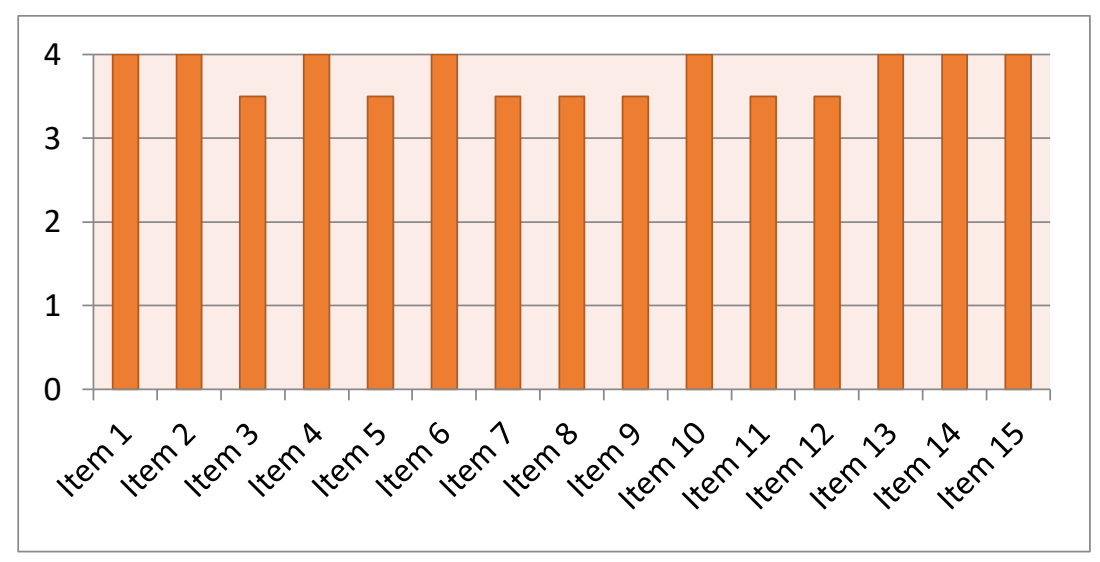

Gambar 6. Respon Siswa

\section{PEMBAHASAN}

Multimedia tutorial yang telah dikembangkan melalui beberapa tahapan dan review oleh ahli media, ahli materi serta uji coba terhadap produk yang melibatkan 6 siswa. Hasil review ahli media dari 11 item pernyataan mendapatkan rerata nilai total 3,72. Ahli media juga menyampaikan komentar dan saran bahwa secara menyeluruh produk yang dikembangkan cukup bagus. Pada aspek desain visual cukup menarik namun masih perlu optimasi dan simplisitas, terutama pada pemilihan font, dan penataan deskripsi konten. Hasil review ahli media keseluruhan mendapatkan respons positif dan layak digunakan untuk media pembelajaran dengan catatan revisi pada penggantian font, dan penataan ulang pada deskripsi konten produk. Dapat disimpulkan bahwa multimedia tutorial yang dikembangkan mempunyai keunggulan pada desain tampilan media yang menarik, sehingga memungkinkan mudah dipahami siswa, membangkitkan memotivasi dan menjadikan siswa lebih tertarik dalam belajar. Pada design isi media juga tersusun secara terstruktur dan tuntas yang dapat membantu siswa dalam pembelajaran yang terprosedur. Sedangkan kekurangan yang harus ditingkatkan lagi yaitu pada aspek desain visual masih perlu optimalisasi dan beberapa penaataan pesan untuk menyesuaikan karakteristik siswa. Pada sekolahan yang bersangkutan mempunyai peluang yang memadai untuk menerapkan multimedia tutorial,yaitu dengan ketersedianya fasilitas sekolah cukup lengkap. Apalagi pada sekolah bersangkutan sudah menerapkan ujian nasional berbasis komputer yang memungkinkan multimedia tutorial bisa menjadi bagian dari uji coba atau latihan dalam ujian nasional berbasis komputer. Namun ada sedikit hambatan yang harus ditangani yakni dimana masih ada sejumlah guru dan siswa yang minim pengetahuan akan teknologi. 
Kemudian hasil review ahli materi telah mendapat nilai yang cukup tinggi yaitu 3,77. Ahli materi menyampaikan saran dan komentar bahwa produk sudah bagus dan materi yang disajikan dalam media sesuai dengan kurikulum yang berlaku pada SDN 1 Sumberdadap Tulungagung. Multimedia tutorial mampu menjadikan siswa tertarik dan terdorong untuk aktif dalam belajar dan berlatih secara mandiri. Materi yang disajikan dikemas kedalam bahasa yang mudah dikomunikasikan untuk siswa kelas $\mathrm{V}$ sekolah dasar. Hasil dari review ahli materi mendapatkan respons positif dan dinyatakan layak dipakai tanpa revisi materi. Beberapa keunggulan yang dimiliki multimedia tutorial yaitu pada kelengkapan serta kedalaman materi yang disampaikan sesuai dengan KD dan kurikulum yang digunakan. Materi disajikan berupa teks, gambar, audio dan video sehingga dapat mendorong keingintahuan siswa. Materi disampaikan secara runtut sesuai konsep dan diikuti dengan latihan evaluasi. Bahasa yang dipakai komunikatif sehingga pesan dan informasi mudah dipahami dan disampaikan. Materi disampaikan dengan dialogis dan interaktif sehingga mampu mendorong siswa dalam mengikuti proses pembelajaran. Materi tersaji sesuai dengan perkembangan intelektual dan perkembangan emosional siswa. Sedangkan kekurangan yang harus ditingkatkan lagi yaitu pada keluasan materi, dan memperbanyak contoh pada kehidupan sehari-hari.

Hasil uji kelayakan produk mendapatkan respon dari sebanyak 6 siswa kelas V sekolah dasar. Dengan tiap-tiap pernyataan pada angket secara menyeluruh rata-rata mendapatkan nilai 4 dan 3. Hal tersebut menandakan siswa lebih tertarik untuk belajar menggunakan multimedia tutorial. Beberapa siswa menyampaikan komentar bahwa belajar menggunakan multimedia tutorial yang disertai rangkaian materi yang terprosedur yang rapi dapat mempermudah belajar. Siswa juga lebih tertarik apabila materi yang disampaikan memuat gambar,video dan audio. Kebanyakan siswa lebih mengingat pesan yang disampaikan melalui tulisan visual dan praktik sendiri. Dalam penyampaian materi memuat simulasisimulasi dan video untuk mempermudah siswa dalam pemahaman terhadap materi yang disajikan (Yuliana, dkk., 2015).

Suratman (2011) berpendapat ada sejumlah indikator pengetahuan prosedural akan tercapai nantinya yaitu pertama mampu menerapkan langkah menjawab yang sesuai, kedua yaitu mampu mengkomunikasikan proses algoritma termuat pada permasalahan, ketiga yaitu mampu memodifikasi prosedur untuk menangani faktor-faktor dalam pemecahan masalah. Dilihat dari pencapaian belajar siswa dengan menggunakan multimedia tutorial berhasil menyelesaikan evaluasi yang tersaji dan mendapatkan peningkatan pada pencapaian evaluasi. Pada akhir evaluasi siswa mampu menjawab pertanyaan lisan oleh guru dengan benar. Hal tersebut membuktikan bahwa siswa paham akan materi yang dipelajari dengan cara tidak menghafalkan. Dengan multimedia tutorial menjadikan pembelajaran siswa lebih bermakna. Penggunaan media tersebut dapat memicu solusi yang lebih dibandingkan media yang lainnya karena penggunaan media ini berdasarkan pada dua indera yang berperan secara bersamaan yaitu indera pengelihatan dan indera pendengaran (Admaja, dkk., 2019).

Disimpulkan bahwa penggunaan multimedia tutorial berdampak positif pada kognitif prosedural. Penggunan media ini dapat memicu solusi yang lebih dibandingkan media yang lainnya karena penggunaan media ini berdasarkan pada dua indera yang berperan secara bersamaan yaitu indera pengelihatan dan indera pendengaran. Selain itu, multimedia tutorial cocok dipakai untuk pembelajaran dalam kelas, kelompok kecil, maupun individu.

Menurut hasil penelitian (Diansyah, 2018) bahwa multimedia model tutorial dinyatakan berhasil saat dimanfaatkan dalam proses meningkatkan pengetahuan siswa, selain itu juga dapat memperbaharui pencapaian belajar siswa dalam ranah pengetahuan yang dimuat dalam kelas eksperimen berada di nilai kategori sedang, dan lebih besar dibanding kelas kontrol serta mendapatkan hasil perbedaan persentase hasil nilai peserta didik yang lumayan jauh antara belajar memanfaatkan multimedia interaktif model tutorial dengan pembelajaran memanfaatkan metode tradisional. Pembelajaran Tutorial yaitu bimbingan belajar memuat pada pemberian arahan, bantuan, petunjuk, dan motivasi agar peserta didik mampu 
belajar secara efisien dan efektif (Mahardika, dkk., (2016). Para siswa menganggap lebih cocok dan percaya diri dalam proses pemahaman materi, sehingga hasil belajar siswa yang dapatkan bertambah sesuai dengan ekspektasi peserta didik masing-masing. Menurut VII, M. K. (2017) tingkat efektifitas media pembelajaran berbasis multimedia tutorial dapat dikategori sangat efektif.

Menurut Sobarna, E. (2014) menjelaskan bahwa respon siswa terhadap penggunaan multimedia interaktif model tutorial pada pembelajaran ilmu pengetahuan alam memiliki nilai rata-rata berkategori tinggi. Pada penelitian yang dilakukan oleh (Anggraeni, dkk., 2019) memaparkan dengan memakai program multimedia tutorial jauh lebih maksimal dari pada hasil belajar siswa tanpa memakai multimedia tutorial serta dari nilai persentase kelas eksperimen lebih tinggi daripada nilai persentase pada kelas terkontrol. Selanjutnya pada penelitian oleh Sembiring, dkk. (2018) menjelaskan bahwa dapat memunculkan pengalaman belajar yang baru dengan pemanfaatan teknologi sebagai media dan berguna untuk membantu pembelajaran bagi peserta didik. Penelitian oleh Wardani, dkk. (2019) multimedia tutorial menjadi pemecah masalah dalam soal media pembelajaran, dengan memanfatkan multimedia tutorial terbukti bahwa bisa menambah nilai positif dari pencapaian belajar peserta didik. Kemandirian belajar siswa akan mendapati proses belajar yang lebih bermakna dibandingkan dengan pembelajaran di kelas (Wardani, dkk., 2019). Multimedia tutorial mencakup audio visual dalam bentuk teks, gambar, animasi, audio, dan video, sehingga memotivasi dan membuat peserta didik tertarik, serta dapat mendukung tercapainya tujuan pembelajaran (Prastiwi, dkk., 2020).

Dalam penelitian pengembangan multimedia tutorial yang dihasilkan bertujuan untuk memfasilitasi dalam kelancaran kognitif prosedural siswa. Untuk memfasilitasi kelancaran kemampuan prosedural maka diperlukan sebuah media pembelajaran agar terprogram secara prosedural. Multimedia sejalan dengan ciri dan tujuan dari multimedia tutorial yang salah satunya yaitu yaitu bersifat individual dan merupakan pembelajaran tuntas dengan tahapan yang sudah tersusun dan disajikan secara prosedural. Dengan demikian kemampuan prosedural dapat difasilitasi dengan pemanfaatan multimedia tutorial. Akan tetapi untuk penggunaan produk multimedia tutorial cukup memakan waktu lumayan lama dalam proses pembuatan, serta fasilitas juga harus mewadai. Dalam mengoperasikan multimedia tutorial masih diperlukan peran guru untuk memantau siswa. Pada multimediaa tutorial siswa sudah dibantu oleh petunjuk dalam program itu sendiri, namun peran guru yang dibutuhkan disini hanya untuk memastikan siswa belajar dengan disiplin hingga menyelesaikan semua tahapan pada multimedia tutorial.

\section{SIMPULAN}

Multimedia tutorial yaitu inovasi media pembelajaran dapat memfasilitasi kognitif prosedural siswa. Dimana untuk meningkatkan kognitif prosedural membutuhkan media yang dapat menyajikan materi secara urut dan dikemas semenarik mungkin melalui kombinasi beberapa media. Multimedia tutorial dapat digunakan secara mandiri dan dapat dipelajari lagi sesuai dengan kemampuan penggunanya. Seperti pada penelitian-penelitian sebelumnya menghasilkan multimedia tutorial mendapatkan respon positif dan mendapatkan kategori layak. Hasil review multimedia tutorial yang dilakukan oleh ahli media, ahli materi dan tanggapan dari siswa memperoleh kesimpulan bahwa multimedia tutorial dapat memfasilitasi kognitif prosedural dengan respon positif dan layak digunakan.

\section{DAFTAR RUJUKAN}

Admaja, A. M., Kuswandi, D., \& Soepriyanto, Y. (2019). Pengembangan Multimedia Tutorial Untuk Guru Dalam Mengembangkan Software Tes Berbasis Komputer. JINOTEP (Jurnal Inovasi dan Teknologi Pembelajaran): Kajian dan Riset Dalam Teknologi Pembelajaran, 5(2), 63-68.

Alessi \& Trollip. (2001). Multimedia for learning: Methods and development. Massachusetts: A Pearson Education. 
Anas, M. A., Soepriyanto, Y., \& Susilaningsih, S. (2019). Pengembangan multimedia tutorial topologi jaringan untuk smk kelas $\mathrm{x}$ teknik komputer dan jaringan. Jurnal Kajian Teknologi Pendidikan, 1(4), 307-314.

Anderson, L.W., \& Krathwohl, D.R. (2010). Kerangka Landasan Untuk Pembelajaran, Pengajaran, dan Assesmen, Terj. Agung Prihantoro Yogyakarta: Pustaka Pelajar.

Anggraeni, R., Sulton, S., \& Sulthoni, S. (2019). Pengaruh Multimedia Tutorial Terhadap Hasil Belajar Bahasa Indonesia. Jurnal Kajian Teknologi Pendidikan, 2(2), 96-101.

Aprianti, Rini. (2014). Kelancaran Prosedural Matematis Siswa dalam Materi Operasi Hitung Pecahan Aljabar Kelas VII SMP. Skripsi: Universitas Tanjungpura Pontianak.

Aryani, T. D., \& Gundo, A. J. (2014). Pemanfaatan media video tutorial pembelajaran sebagai upaya peningkatan kemampuan kognitif dan psikomotor siswa kelas xii 2 pada mata pelajaran tik di SMAN 1 Ampel.

Diansyah, A. N. (2018). Penerapan Multimedia Interaktif Model Tutorial Terhadap Peningkatan Pemahaman Konsep Siswa Pada Mata Pelajaran Teknologi Informasi Dan Komunikasi. Jurnal Petik, 1(1), 11.

Dewanti, H., Toenlioe, A. J., \& Soepriyanto, Y. (2019). Pengembangan Media Pop-Up Book Untuk Pembelajaran Lingkungan Tempat Tinggalku Kelas Iv Sdn 1 Pakunden Kabupaten Ponorogo. Jurnal Kajian Teknologi Pendidikan, 1(3), 221-228.

Hanim, F., Sumarmi, S., \& Amirudin, A. (2016). Pengaruh Penggunaan Multimedia Pembelajaran Interaktif Penginderaan Jauh Terhadap Hasil Belajar Geografi. Jurnal Pendidikan: Teori, Penelitian, dan Pengembangan, 1(4), 752-757.

Hartono, W. \& Noto, MS. (2017). Pengembangan Modul Berbasis Penemuan Terbimbing untuk Meningkatkan Kemampuan Matematis pada Perkuliahan Kalkulus Integral. Juranal JNPM (Jurnal Nasional Pendidikan Matematika). Vol. 1 No. 2 Hal. 320-333.

Jannah, I. N. (2020). Efektivitas Penggunaan Multimedia dalam Pembelajaran IPA di SD. Jurnal Ilmiah Sekolah Dasar, 4(1), 54-59.

Khamidah, L. (2017). Pemahaman Konseptual Dan Pengetahuan Prosedural Siswa Kelas VIII Dalam Penyelesaian Soal Matematika Pada Materi Sistem Persamaan Linier Dua Variabel. In Prosiding SI MaNIs (Seminar Nasional Integrasi Matematika dan Nilai-Nilai Islami) (Vol. 1, No. 1, pp. 611-616). 3

Kurniawati, I. D., \& Nita, S. (2018). Media Pembelajaran Berbasis Multimedia Interaktif Untuk Meningkatkan Pemahaman Konsep Mahasiswa. Doubleclick: Journal of Computer and Information Technology, 1(2), 68.

Larasati, F.A. dan Yunianta, T. N. H. (2017). Analisis Kelancaran Prosedural Siswa Sekolah Menengah Pertama pada Materi Operasi Aljabar. Jurnal Mitra Pendidikan. Vol.1 No.10 Hal.9951006

Lee, W. W., \& Owens, D. L. (2004). Multimedia-based instructional design: computer-based training, web-based training, distance broadcast training, performance-based solutions. John Wiley \& Sons.

Mahardika, K. M., Suwatra, I. I. W., \& Suartama, I. K. (2016). Pengembangan multimedia pembelajaran interaktif model tutorial mata pelajaran ipa kelas viii semester genap di smp negeri 6 singaraja tahun pelajaran 2015/2016. Jurnal Edutech Undiksa, 4(2).

Mahnun, N. (2012). Media pembelajaran (kajian terhadap langkah-langkah pemilihan media dan implementasinya dalam pembelajaran). An-Nida', 37(1), 27-34.

Paridjo, P. (2019). Analisis Kemampuan Pemecahan Masalah Mahasiswa Pendidikan Matematika Ditinjau Dari Kesalahan Konseptual dan Prosedural. In Prosiding Seminar Nasional MIPA Kolaborasi (Vol. 1, No. 1, pp. 231-242). 
Prastiwi, D. N., Setyosari, P., \& Husna, A. (2020). Pengembangan Multimedia Tutorial sebagai Suplemen pada Mata Pelajaran Kimia Materi Asam dan Basa Kelas XI. JINOTEP (Jurnal Inovasi dan Teknologi Pembelajaran): Kajian dan Riset Dalam Teknologi Pembelajaran, 6(2), 69-80.

Prayoga, G. S., Sudarma, I. K., \& Tegeh, I. M. (2016). Pengembangan Multimedia Interaktif Model Tutorial Pada Mata Pelajaran PKN Kelas VIII Semester Genap Di SMP Negeri 6 SingaRaja Tahun Pelajaran 2015/2016. Jurnal Edutech Undiksha, 4(2).

Sembiring, E. B., Wahyuni, D., \& Anurogo, W. (2018). Multimedia Interaktif Pengenalan Hewan dan Tumbuhan Langka Menggunakan Model Tutorial. Journal of Digital Education, Communication, and Arts, 1(2), 103-112.

Sobarna, E. (2014). Efektifitas Penggunaan Multimedia Interaktif (Mmi) Model Tutorial Terhadap Motivasi Serta Hasil Belajar Peserta Didik Pada Materi Pelajaran Ilmu Pengetahuan Alam Pokok Bahasan Sistem Pernapasan Manusia. EDUTECH, 13(3), 386-399.

Wardani, S. K., Setyosari, P., \& Husna, A. (2019). Pengembangan Multimedia Tutorial Mata Pelajaran IPA Pokok Bahasan Sistem Tata Surya Kelas VII MTS Raudlatul Ulum. Jurnal Kajian Teknologi Pendidikan, 2(1), 23-29.

Yuliana, F. H., \& Jaenudin, R. (2015). Pengaruh Pembelajaran Berbasis Komputer Model Tutorial Terhadap Hasil Belajar Siswa Pada Mata Pelajaran Ekonomi Di SMA Muhammadiyah 1 Palembang. In Prosiding Seminar Nasional Pendidikan Ekonomi \& Bisnis, Sabtu (Vol. 7).

VII, M. K. (2017). Efektifitas media pembelajaran matematika menggunakan software animasi berbasismultimedia interaktif model tutorial pada materi. Jurnal Penelitian Pembelajaran Matematika Sekolah (JP2MS), 1(1). 